\title{
SISTEM PENUNJANG DAN SARANA PEMEROLEHAN BAHASA KEDUA PADA ANAK
}

\author{
Syafi'i Zaini \\ Dosen Universitas Muslim Nusantara ( UMN ) Al-Washliyah \\ Jln. Garu II Medan
}

\begin{abstract}
Abstrak
Pemerolehan bahasa atau akuisisi bahasa adalah proses yang berlangsung di dalam otak kanak-kanak ketika dia memperoleh bahasa pertamanya atau bahasa ibunya. Pemerolehan bahasa biasanya dibedakan dengan pembelajaran bahasa. Pembelajaran bahasa berkaitan dengan proses-proses yang terjadi pada waktu seorang kanak-kanak mempelajari bahasa kedua setelah dia memperoleh bahasa pertamanya. Performansi adalah kemampuan anak menggunakan bahasa untuk berkomunikasi dlah satu sistem penunjang pemerolehan bahasa kedua pada anak . Performansi terdiri dari dua proses, yaitu proses pemahaman dan proses penerbitan kalimat-kalimat. Proses pemahaman melibatkan kemampuan mengamati atau mempersepsi kalimat-kalimat yang didengar, sedangkan proses penerbitan melibatkan kemampuan menghasilkan kalimat-kalimat sendiri.
\end{abstract}

Kata kunci : sarana pemerolehan bahasa

\begin{abstract}
Language acquisition or language acquisition is a process that takes place in a child's brain when he or she gets his first language or his mother tongue. Language acquisition is usually distinguished by language learning. Language learning deals with the processes that occur when a child learns a second language after he or she gets his first language. Performance is the ability of children to use language to communicate dlah a second language acquisition support system in children. Performance consists of two processes, namely the process of understanding and the process of publishing sentences. The process of understanding involves the ability to observe or perceive the sentences heard, while the publishing process involves the ability to produce sentences themselves.
\end{abstract}

Keywords: language acquisition means

\section{Pendahuluan}

\subsection{Latar Belakang Masalah}

Komponen yang paling mendasar dan paling fundamental dari '" sistem penunjang pemerolehan bahasa " atau yang dalam bahasa inggris "languageacquisition support system" adalah bahwa system ini menyediakan atau memberi kesempatan yang mudah untuk menggunakan bahasa kedua sebagai alat komunikasi. Dikehidupan sekarang ini seorang anak tidak hanya memiliki bahasa ibu. Seorang anak juga memiliki bahasa kedua dalam berkomunikasa dan berinteraksi dengan orang lain dilingkunganya. Proses pemerolehan 
bahasa kedua pada anak memerlukan system dan sarana agar bahasa tersebut dapat diperoleh dengan cepat,tepat dan optimal.Bahasa kedua merupakan alat komunikasi yang penting bagi seorang anak untuk berinteraksi dengan orang lain di lingkungan di luar dari tempat tinggalnya.

Seorang anak yang berinisial FL merupakan seorang anak yang berasal dari Tamiang, Sumatra Utara. Kedua orangtuanya merupakan suku Tapanuli Selatan, sehingga bahasa pertama yang diperoleh FL adalah bahasa mandailing dikarenakan bahasa tersebutlah yang yang pertama kali dikenalkan orangtuanya kepadanya. Komunikasi yang dipakai FL dengan keluarganya memakai bahasa mandailing dengan dialek yang kental. Ketika FL berusia 6 tahun, dia pindah ke Pematangsiantar. Kepindahanya karena Bapaknya pindah kerja ke Pematangsiantar, sehingga FL harus bersekolah di Pematangsiantar. Ketika FL masuk Taman Kanakkanak, dia mengalami kesulitan untuk berkomunikasi dengan temannya dan memperoleh serta mempelajari bahasa keduanya.Hal ini karena FL terbiasa bahasa mandailing.Hal ini menimbulkan pertanyaan yaitu sistem dan sarana apakah agar FL memperoleh bahasa Indonesia secara optimal sebagai bahasa keduanya ?

\section{Pembahasan}

FL seorang anak yang memiliki orangtua dari Tamiang yang selalu berkomunikasi dengan FL dan keluarga yang lain dengan menggunakan bahasa mandailing. Ketika FL masuk masuk TK, FL mengalami kesulitan berkomunikasi dengan teman dan gurunya. Kesulitan yang dialami FL karena dia berasal dari latar belakang dan suku yang berbeda. Maka FL harus mempelajari bahasa Indonesia sebagai bahasa keduanya. Adapun system dan sarana pemerolehan bahasa tersebut adalah :

\section{Gunakan bahasa khusus}

Maksudnya adalah menggunakan bahasa yang sering digunakan para ibu dan para pengasuh lainnya waktu berhadapan dengan anak-anak. Ciri-ciri khususbahasa keibuan adalah bahasanya diucapkan kebih lambat, lebih baik dan lebih jelas daripada 
diucapkan orang dewasa dengan sesamanya.

\section{Gunakan segala sesuatu yang menarik hati}

Seorang anak yang sedang memperoleh bahasa kedua seringkali mengalami kesulitan karena cara yang dipakai terlalu memeksa anak sehaingga anak menjadi bosan dan jenuh. Kita sebagai guru atau orangtuanya harus memberikan cara yang disukai anak tersebut dan menarik. Cara-cara yang dipakai bisa saja menggunakan gambar,bunyi (lagu) dan yanglainnya yang variatif. Hal ini dipakai agar FL tertarik dalam mempelajari bahasa Indonesia sebagai bahasa keduanya.

\section{Gunakan benda serta kata-kata yang mudah dipahami anak}

Siasat ini menekankan jika kita mengajari anak untuk memahami bahasa keduanya, hendaknya dimulai dari kata benda yang sering dilihatnya beserta contohnya. Serta berikan anak tersebut kata-kata yang mudah dipahaminya sehinga anak tersebut akan mudah untuk mengingatnya.

\section{Berikan kesempatan berkomunikasi}

Seorang anak yang sedang mempelajari bahasa kedua harus diberi kesempatan untuk berkomunikasi dengan temannya dan gurunya.Walaupun bahasa yang dipakai pada saat berkomunikasi masih ada kesalahan yang dilakukan serta dialek yang kental saat berkomunikasi.

\section{Memberikan pertanyaan yang sederhana}

Seorang anak yang sedang dalam proses pemerolehan bahasa kedua harus sering kata beri partanyaan yang sederhana agar anak tersebut dapat menjawab dengan mengutarakan kosa kata yang telah dia kuasai dan mengutarakan isi hatinya.

6. Penyusunan kembali kata-kata sederhana yang telah diucapkan

Pembelajaran ini merupakan suatu pembelajaran bagai mana cara menggabungkan kata-kata menjadi ujaran percakapan. Penyusunan kembali juga melibatkan beberapa pengulangan dari apa yang telah dikatakan oleh anak diulang apakah ada penambahan atau pangurangan kata.

\section{Belajar dari masukan yang} diterima

Seorang anak yang sedang belajar pemerolehan bahasa kedua 
harus menerima masukan-masukan dari teman, guru dan orangtuanya. Tetapi masukan yang diberikan harus disederhanakan agar anak tersebut daoat menerimanya dan memahami masukan tersebut.

\section{Simpulan}

Berdasarkan uraian di atas, maka dapat disimpulkan bahwa apabila system penunjang dan sarana pemerolehan bahasa tersebut diterapkan oleh guru, orang tua, maupun pihak lain, maka anak-anak seperti FL akan dapat mengatasi kesulitan dan masalahnya dalam memperoleh bahasa kedua dengan baik dan optimal.

\section{Daftara Pustaka}

Chomsky, Noam. 1975. Reflections and Language. New York: Pantheon Books.

Ellis, Rod 1984. Classroom Second Language Development. Oxford: Pergamon.

Ellis, Rod. 1986. Understanding Second Language Acquisition Oxford: Oxford University Press.

Gass, Susan M dan Selinker. 1994. Second Language Acquisition: An Introduction Course. Hillsdale: Lawrence Erlbaum Associates, Inc.

Giles, Fl dan J: Birne. 1982. An Intergroup Approach Second Language Acquisition. Jurnal of
Multilingual and Multicultural Development, 3,17-40.

Hatctt, E. 1978a. Second Language Acquisition. Rowly, Mass: Newbury House.

Hymes, Dell. 1983. On Communicative Competence. Philadelpia: University of Pennsylvania Press. 